\title{
STUDY OF CANCER PATIENTS' \& CANCER SURVIVORS' MENTAL STATES
}

Margaryan T. H. (Queen Mary University, London, United Kingdom) tatev.margaryan.00@mail.ru

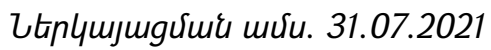

9pmunuर्uir mú. 26.08.2021

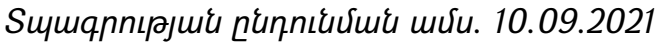

Cancer is the second leading cause of death in the world and is responsible for an estimated 10 million deaths in 2020. Globally, about 1 in 6 deaths is due to cancer. Even though the global health care quality has improved in the last decades, cancer is still a vague and unpredictable illness that leaves major and mild psychological side-effects, which follows a person even in survivorship.

Cancer affects many aspects of the mental state, especially the emotional sphere of a person. Most commonly fear, stress, anxiety, sadness and frustration are the leading emotions when a person is dealing with cancer. In this study we will try to show the range of cancer's impact on cancer patients' and cancer survivors' mental states.

Keywords. Cancer, mental state, patients, depression, anxiety, survivors.

DOI: https://doi.org/10.46991/SBMP/2021.4.2.237

Cancer is a medical illness that affects not only the physical health of a person but also their mental health. As a very complicated and unpredictable illness, cancer

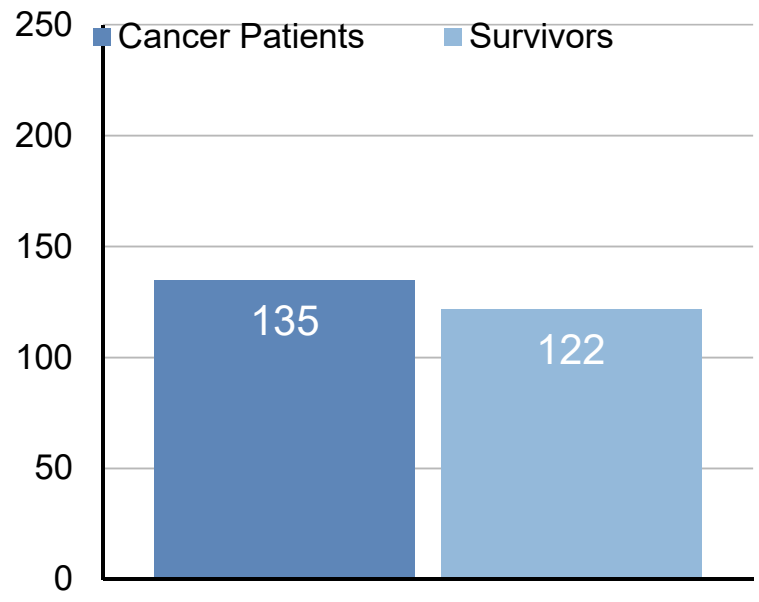

Fig. 1 General average levels of stress brings many challenges for patients and even for cancer survivors. Cancer patients and their families face multiple challenges in the areas of resuming and maintaining life activities, coping with treatment and side-effects, managing the emotional impact and stresses and adjusting to significant long-term losses and changes. The complexity and severity of these challenges reflect the complexity and severity of 


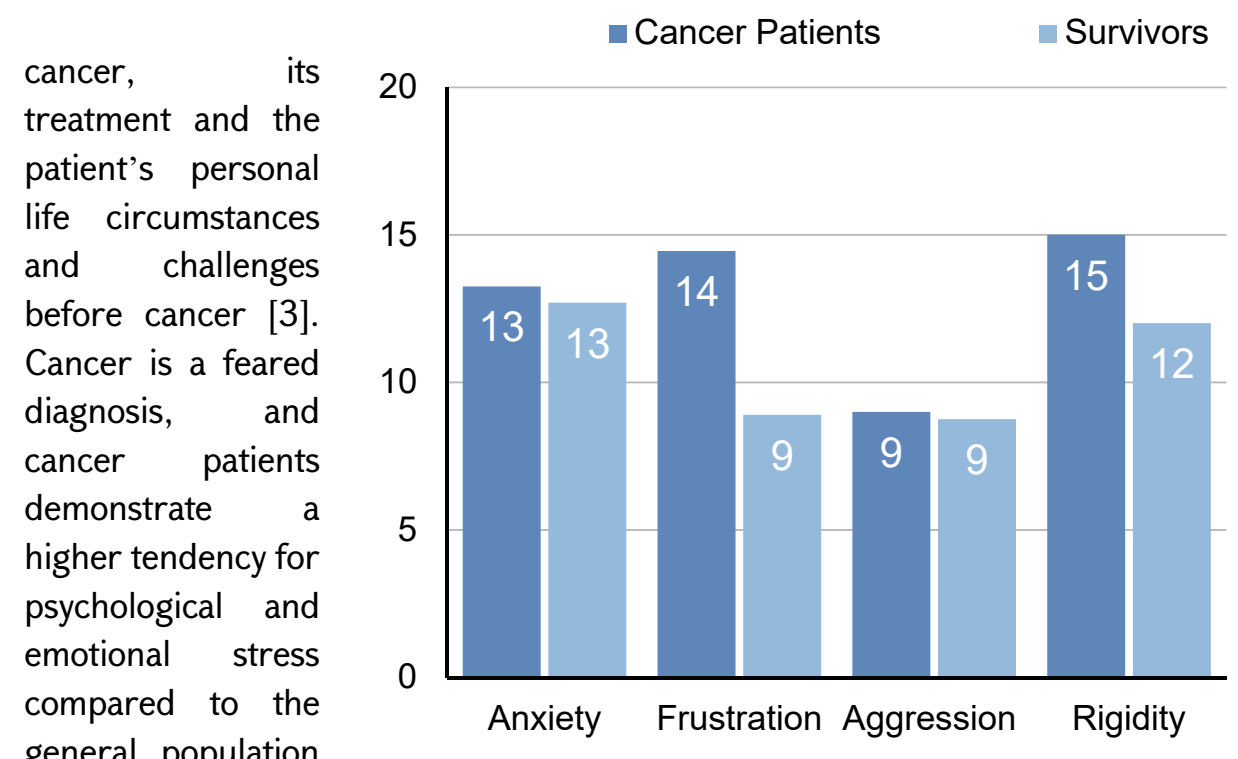

Fig. 2 General average of emotional levels

[1]. The psychological impact and emotions experienced by survivors are varied. Some reactions are more common than others, including the onset of depression, anxiety, and sexual dysfunction and feelings of abandonment, isolation, grief, and fear of recurrence. Body image and sexuality are also commonly impacted by cancer [4].

One of the major psychological disruptions caused by cancer and its treatment is the fluctuation of the emotional state. Both cancer patients and survivors have this in common, despite cultural differences, as they experience high levels of anxiety, stress [2], fear, anger, etc., even if the factors contributing to these emotional changes are different for each group.

Methods. The purpose of this study is to compare the mental/emotional states of adult cancer patients and cancer survivors from different cultures by using two psychological questionaries. These questionaries are Robert Dato- the strategic stress management test, and Hans Eysenck- emotional state assessment test. R. Dato's test is designed to determine the level of stress, while H. Eysenck's test's purpose is to measure the levels of anxiety, frustration, aggression and rigidity.

The study has 40 cancer patient participants and 40 cancer survivor participants of different cultures.

Results. According to the collected data, there is a wide prevalence of emotional disturbances in both cancer patients and survivors. It is evident from 
figure 1 that both cancer patient and survivor participants have the same low level of stress, but if we take into consideration the numbers collected, we can distinguish the difference between these groups. Although both groups fall into the same stress level, cancer patients have a slightly higher level of stress on average than cancer survivor participants.

Of the total sample in the study, there was $66,7 \%$ for the low level of stress, $22,3 \%$ for a moderate level of stress and $11 \%$ for a very low level of stress. As it can be seen, there was no recorded level of stress higher than moderate. As surprising as it is, none of the participants had a severe level of stress, according to the method used.

Now for the other mental state indicators, that you can see in figure 2. As is illustrated in the bar chart (fig. 2), in general, cancer patient-participants have more expressive results than cancer survivor participants. All of the recorded results of all four aspects of mental states (anxiety, frustration, aggression, rigidity) are of moderate level, the only exception is the level of rigidity in cancer patients, which stands on the line between severe and moderate levels of rigidity. There is a similarity in cancer survivor participants 'results of anxiety and rigidity, as well as frustration and aggression. Both levels of anxiety and rigidity in cancer survivors was over 12 (moderate level), and frustration and aggression levels were over 8 , reaching 9 (moderate level). Furthermore, it can also be noted, that this is also similar to the aggression level of cancer patient-participants.

Again, even though all of the results in all four emotional aspects are of moderate level, differences can be detected in-between the spectre of moderate level, especially between the results of cancer survivors and cancer patients. Cancer patients had considerably higher levels of frustration and rigidity than cancer survivors, almost reaching the highest level. And lastly, the level of anxiety in both cancer patients and survivors is quite similar, although cancer patients still had a higher level of anxiety than the latter.

Conclusion. As it has become apparent from the result of our study, cancer patients have a higher prevalence of all five aspects of mental state indicators, which were included in our research. According to the methods used, every cancer patient participant recorded higher stress, anxiety, aggression, frustration and rigidity levels, than that of cancer survivors.

Despite the claim above, cancer survivor participants 'results were not as different from those of cancer patient-participants. Although cancer patients indeed had higher levels of all the mental state aspects studied by us, cancer survivor participants 'results and cancer patient participants 'results were very close in average numbers, making them all stand in moderate levels of all five mental state aspects studied, with the cancer patients 'results appearing little higher. 
In conclusion, the average level of stress, anxiety, frustration, aggression and rigidity for both cancer patients and cancer survivors were of moderate level, although distinguishing differences can be determined by looking at the average numbers of the results. By analysing these results we have concluded, that cancer patients recorded higher levels of all five aspects of mental state indicators studied by us in this research.

\section{References}

1. American Cancer Society. Anxiety, Fear, and Depression. 2016; Available from: http:// www.cancer.org/acs/groups/cid/documents/ webcontent/002816-pdf.pdf

2. Anxiety and stress- Cancer Treatment Centers of America, July 16, 2021, reviewed and approved by Maurie Markman, MD, President, Medicine \& Science at CTCA

3. Background to the Cancer Psychology Referral Guidelines- Robin Paijmans Macmillan Clinical Psychologist, 2010

4. Burney S. Psychological issues in cancer survivorship. Climacteric. 2019 Dec;22(6):584-588. doi: 10.1080/13697137.2019.1606795. Epub 2019 May 13. PMID: 31079545.

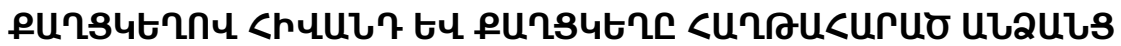

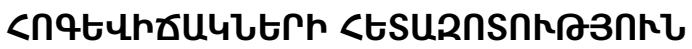

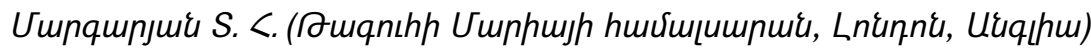

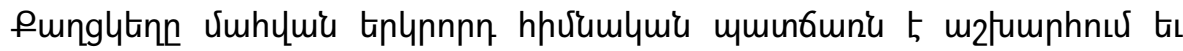

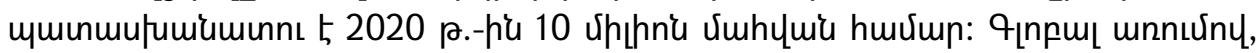

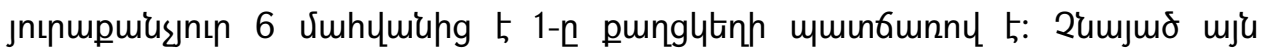

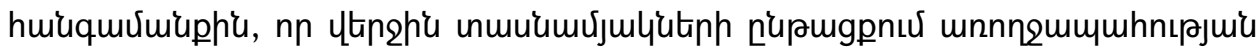

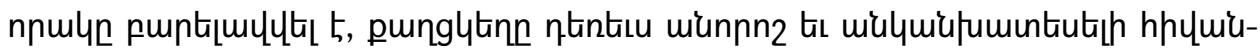

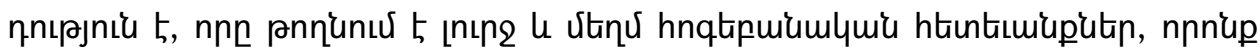

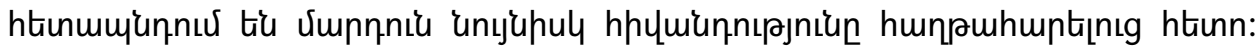

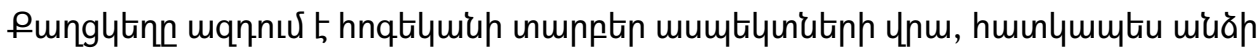

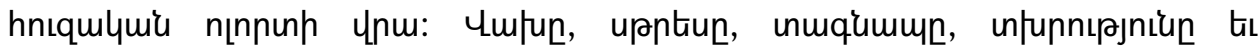

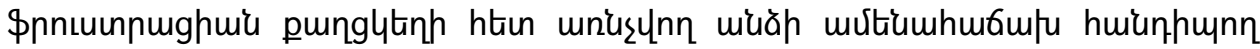

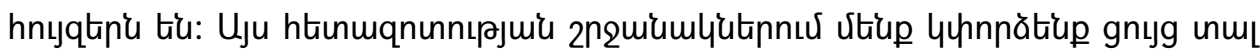

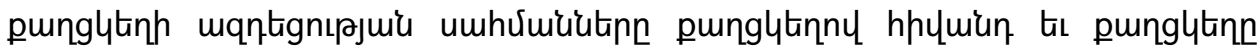

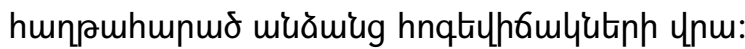


<uirqnıgujhis punte' pungltin, snuquimu, hhymunqutin, hnqtilhtiml,

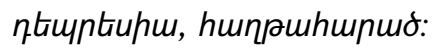

\section{ИССЛЕДОВАНИЕ ПСИХОЛОГИЧЕСКОГО СОСТОЯНИЯ БОЛЬНЫХ РАКОМ И ЛЮДЕЙ, ПЕРЕЖИВШИХ РАК.}

Маргарян Т. А. (Лондонский университет королевы Марии, Лондон, Англия)

Рак является второй причиной смерти в мире: по данным 2020 года от этого заболевания умерли около 10 миллионов человек. Примерно каждая шестая смерть во всем мире является последствием данной болезни. Несмотря на то, что в последние несколько десятилетий качество здравоохранения улучшилось, раковая болезнь по-прежнему остается неопределенным и непредсказуемым, оставляя как легкие, так и серьезные побочные эффекты психологического характера, которые преследуют человека даже после того, как он поборол эту болезнь.

Рак влияет на многие аспекты психического состояния человека, и в особенности на его эмоциональную сферу. Чаще всего страх, стресс, беспокойство, грусть и разочарование выступают основными испытываемыми эмоциями, когда человек сталкивается с раком.

В рамках данной исследовательской работы мы попытаемся показать диапазон воздействия ракового заболевания на психическое состояние как больных, так и переживших данную болезнь людей.

Ключевые слова: рак, тревожность, пачиенты, психическое состояние, депрессия, поборовший 